\title{
GCG DAN CSR DALAM MEMPENGARUHI EARNINGS MANAGEMENT (BUKTI PADA PERUSAHAAN SEKTOR FOOD AND BEVERAGE YANG TERDAFTAR DI BEI TAHUN 2014-2019)
}

\author{
${ }^{*}$ Febriani Nur Azizah ${ }^{1}$, Didin Fatihudin ${ }^{2}$ Marista Oktaviani ${ }^{3}$ \\ 1,2,3Prodi Manajemen, Fakultas Ekonomi dan Bisnis, Universitas Muhammadiyah Surabaya \\ ${ }^{*}$ febrianina28@gmail.com
}

\begin{tabular}{l}
\hline Informasi Artikel \\
\hline Draft awal: Januari 2021 \\
Revisi : Januari 2021 \\
Diterima : Maret 2021 \\
Available online: Maret 2021 \\
\hline
\end{tabular}

Keywords: $G C G, C S R$,Earning Management

Tipe Artikel : Research paper

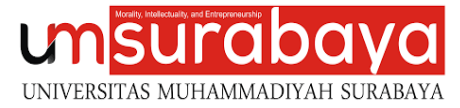

Diterbitkan oleh Universitas Muhammadiyah Surabaya

\begin{abstract}
This research was conducted to determine the effect of the GCG and CSR variables on Earnings Management. This research method used a quantitative approach and secondary data collection techniques using annual reports (annual reports) available on the Indonesia Stock Exchange (BEI) in 2014. 2019. The population numbered 14 companies and a sample of 7 companies with purposive sampling technique. Data processing techniques used PLSSEM.. The GCG variable was proxied by Institutional Ownership, Managerial Ownership, and the Board of Commissioners. The results show that the results of the GCG and CSR have positive effect on Earning Management.
\end{abstract}

Penelitian ini dilakukan untuk mengetahui pengaruh dari GCG dan CSR terhadap variabel Earning Management. Metodenya menggunakan kuantitatif dan data sekunder yang didapatkan dari laporan tahunan yang tersedia di BEI tahun 2014-2019. Populasinya 14 perusahaan dan sampel yang diambil sebanyak 7 perusahaan. Proses analisis data menggunakan PLS-SEM. Variabel GCG diproksikan dengan kepemilikan institusional dan dewan komisaris. Hasil penelitian menunjukkan bahwa GCG dan CSR berpengaruh positif terhadap Earning Management

\section{PENDAHULUAN}

Pertumbuhan industri makanan dan minuman di Indonesia yang terus meningkat dan menjadi salah satu sektor manufaktur andalan dalam memberikan kontribusi yang besar terhadap pertumbuhan ekonomi Indonesia. Kementerian Perindustrian mencatat, sepanjang tahun 2018, industri makanan dan minuman mampu tumbuh sebesar 7,91 persen atau melampaui pertumbuhan ekonomi nasional di angka 5,17 persen (Pratiwi, 2019). Laporan keuangan dan laporan tahunan merupakan bentuk informasi atau pertanggungjawaban manajer kepada para stakeholders perusahaan yang wajib dipublikasikan. Laporan keuangan dan laporan tahunan mempunyai tujuan untuk memberikan informasi tentang kinerja keuangan, posisi keuangan dan arus kas, informasi tersebut harus menunjukkan kondisi keuangan yang sebenarnya sehingga dapat bermanfaat bagi para stakeholder (S. Willy Rahadyan, 2015).

Informasi yang tidak sepenuhnya disampaikan oleh manajer kepada para pemegang saham menyebabkan adanya asimetri informasi.
Penyalahgunaan laporan keuangan terjadi karena adanya ketidakselarasan antara pihak pemegang saham dan manajer yang disebut sebagai hubungan agensi (Beneish, 2001). Menurut Mahariana dan Ramantha (2014) pihak manajemen melakukan praktik manajemen laba karena untuk memenuhi tujuan pribadi dan pemanfaatan celah disaat penyusunan laporan keuangan sehingga manajer dapat mengatur laba dengan cara menurunkan, menaikkan, atau menyamaratakan laba.

Manajemen laba dipengaruhi oleh beberapa faktor diantaranya adalah melaksanakan mekanisme Good Corporate Governance dan pengungkapan Corporate Social Responsibility. Menurut Forum for Corporate Governance in Indonesia atau FCGI tahun 2001 tujuan Corporate Governance adalah mengendalikan perlikau pengelola perusahaan agar tidak bertindak untuk menguntungkan dirinya sendiri tetapi juga untuk menguntungkan perusahaan sehingga dapat menyamakan kepentingan antara pemelik dan pengelola perusahaan (Dewi, Ayu, dan Eka, 2019). Mekanisme Good Corporate Governance dapat diukur dengan menggunakan kepemilikan institusional, kepemilikan manajerial, 
dewan komisaris dan komite audit yang diharapkan dapat meningkatkan pengawasan terhadap manajemen dan mencegah terjadinya tindakan manajemen laba.

$\begin{gathered}\text { Pengungkapan } \\ \text { Responsibility }\end{gathered}$
$\begin{gathered}\text { Corporate } \\ \text { merupakan }\end{gathered}$ $\begin{array}{r}\text { Social } \\ \text { bentuk }\end{array}$ pertanggungjawaban setiap perusahaan kepada para stakeholders dan masyarakat. Kegiatan Corporate Social Responsibility sekarang sudah bersifat wajib yang harus dilakukan oleh setiap perusahaan untuk bertanggung jawab dalam aspek ekonomi, sosial dan dan lingkungan. Dalam Undang-undang Nomor 40 tahun 2007 tentang Perseroan Terbatas, tanggung jawab sosial dan lingkungan diatur dalam pasal 74 ayat (1).

Menurut Ratmono, Purwanto, dan Cahyonowati (2015) Corporate Social Responbility mampu meningkatkan citra suatu perusahaan dengan memberikan reputasi perusahaan yang baik. Meningkatkan citra perusahaan mampu mempertahankan maupun menarik para investor, dan jika pihak manajemen menjaga reputasi perusahaan dengan baik maka dapat mencegah terjadinya praktik manajemen laba.

Menurut Penelitian Abduh dan Rusliati (2018), Kepemilikan Institusional berpengaruh terhadap manajemen laba, sedangkan Kepemilikan manajerial, dewan komisaris independen dan komite audit tidak berpengaruh terhadap manajemen laba. Namun penelitian yang dilakukan oleh (Asward dan Lina, 2015), dengan proporsi Kepemilikan Institusional, Kepemilikan manajerial, dan Komite audit berpengaruh terhadap manajemen laba, dan dewan komisaris tidak berpengaruh terhadap manajemen laba.

Pengungkapan CSR diukur menggunakan CSRI (Corporate Social Responbility Index). Penelitian terdahulu terkait pengungkapan CSR (Ardiani dan Sudana, 2018) menemukan bahwa pengungkapan CSR tidak berpengaruh terhadap manajemen laba dikarenakan semakin tinggi intensitas pengungkapan CSR maka perusahaan tersebut dapat meminimalisir terjadinya praktik manajemen laba. Pada penelitian yang dilakukan (Arief dan Ardiyanto, 2014) Pengungkapan CSR berpengaruh tidak signifikan terhadap manajemen laba, karena hasil yang dilakukan menunjukkan bahwa tidak menjamin jika semakin besar pengungkapan informasi CSR maka kesempatan pihak manajemen untuk melakukan praktik manajemen laba

\section{Agency Theory}

Teori keagenan adalah teori yang menjelaskan tentang hubungan antara pemilik dan manajemen. Teori keagenan merupakan sebuah kontrak antara satu atau dua lebih orang manajer (agent) dengan investor (principal) yang mendelegasikan beberapa kewenangan untuk membuat keputusan kepada agent. Masalah agensi adalah masalah yang timbul karena terjadi konflik kepentingan antara agent dan principal. Konflik kepentingan antara agent dan principal sering terjadi di perusahaan karena agent dan principal saling memaksimalkan kepentingan mereka (Jensen dan Meckling, 1976).

\section{Stakeholder Theory}

Teori stakeholder menjelaskan bahwa perusahaan bukanlah entitas yang beroperasi untuk kepentingan individu namun juga memberikan manfaat kepada para stakeholder yang lebih luas. Lingkungan merupakan salah satu aspel yang penting bagi perusahaan yang bergerak di bidang pemanfaatan atau pengelolaan sumber daya alam.

\section{Legitimacy Theory}

Teori legitimasi digunakan sebagai dasar pengungkapan Corporate Social Responsibility di perusahaan. Teori legitimasi adalah sebagai system orientasi perspektif dimana perusahaan dapat mempengaruhi dan dipengaruhi oleh masyarakat di lingkungan perusahaan dalam melakukan aktivitasnya (Deegan, Rankin, dan Tobin, 2002). Suatu perusahaan melakukan legitimasi keberadaannya dalam masyarakat dengan mengikuti norma-norma yang ada dan disetujui oleh masyarakat (Anas, Rashid, dan Annuar, 2015).

\section{Earnings Management}

Manajemen laba adalah sebagai pilihan kebijakan akuntansi yang dilakukan oleh manajer atau tindakan nyata yang dapat mempengaruhi pendapatan untuk tujuan spesifik. Manajemen laba dapat dilihat dari dua perspektif yaitu, perspektif sebagai perilaku oportunis manajer untuk memaksimalkan utilitasnya dan perspektif efficient contracting (Scott, 2015).

Manajemen laba terdapat beberapa pola yaitu, Taking a bath, Income minimization, income maximization, dan income smoothing. Pola taking a bath dilakukan ketika perusahaan mengalami kondisi buruk, pola income minimization dilakukan dengan meminimalisasi pendapatan, pola income maximization dilakukan dengan memaksimalkan laba, dan income smoothing dilakukan dengan cara perataan laba yang dilaporkan.

\section{Good Corporate Governance}

Good Corporate Governance menurut Forum Corporate Governance Indonesia (FCGI, 2002) yang menggnakan definisi cadburry committee, good corporate governance didefinisikan sebagai 
seperangkat peraturan yang mengatur hubungan antara pemegang saham, pengurus atau pengelola perusahaan, baik pihak kreditur, pemerintah, karyawan serta para pemegang saham kepentingan intern dan ekstern lainnya yang berkaitan dengan hak-hak kewajiban perusahaan.

Good Corporate Governance terdiri dari 5 asas yang harus diterapkan yaitu:

1. Transparansi (Transparancy): Perusahaan harus membuat informasi yang material dan relevan dengan cara yang mudah di akses dan dipahami oleh para stakeholders.

2. Akuntantabilitas (Accountability): Perusahaan harus dapat mempertanggung jawabkan kinerjanya secara transparan dan wajar. Dan perusahaan harus dikelola dengan benar, terstruktur dan sesuai dengan kepentingan perusahaan dengan tetap memperhatikan kepentingan para stakeholders.

3. Pertanggungjawaban (Responsibility): perusahaan harus mematuhi peraturan perundang-undangan yang ada, dan melaksanakan tanggung jawab kepada masyarakat dan lingkungan.

4. Kemandirian (Idependency): Perusahaan harus dikelola secara independen oleh kekuasaan yang seimbang, tidak ada salah satu perseorangan perusahaan yang saling mendominasi dan tidak dapat diintervensi oleh pihak lain.

5. Kewajaran dan kesetaraan (Fairness): Perusahaan harus memperhatikan kepentingan pemegang saham dan para stakeholders berdasarkan asas kewajaran dan kesetaraan, dan perusahaan memberikan kesempatan kepada para stakeholders untuk menyampaikan pendapat.

\section{Corporate Social Responsibility}

Corporate Social Responsibility merupakan kegiatan pertanggungjawaban perusahaan kepada para stakeholders dan masyarakat dalam melakukan aktivitas perusahaan yang berdampak pada lingkungan sekitar. Menurut Ricardo dan Faisal (2015) bahwa corporate social responsibility merupakan strategi perusahaan yang mengakomodasi kebutuhan dan kepentingan stakeholders untuk tujuan pertumbuhan berkelanjutan, perusahaan tidak hanya mengambil manfaat sendiri namun juga berperan dalam pertumbuhan masyarakat dan lingkungan.

Kegiatan corporate social responsibility merupakan kegiatan yang bersifat wajib yang harus dilakukan oleh setiap perusahaan untuk bertanggungjawab dalam aspek ekonomi, sosial dan lingkungan. Pemerintah Indonesia telah mengatur dalam UU Nomor 40 tahun 2007 tentang perseroan terbatas. Pada pasal 74 UU Nomor 40 tahun 2007, menyatakan bahwa perusahaan yang menjalankan kegiatan usahanya di bidang yang berkaitan dengan sumber daya alam wajib melaksanakan tanggung jawab sosial dan lingkungan.

\section{METODE}

\section{Kerangka Konseptual}

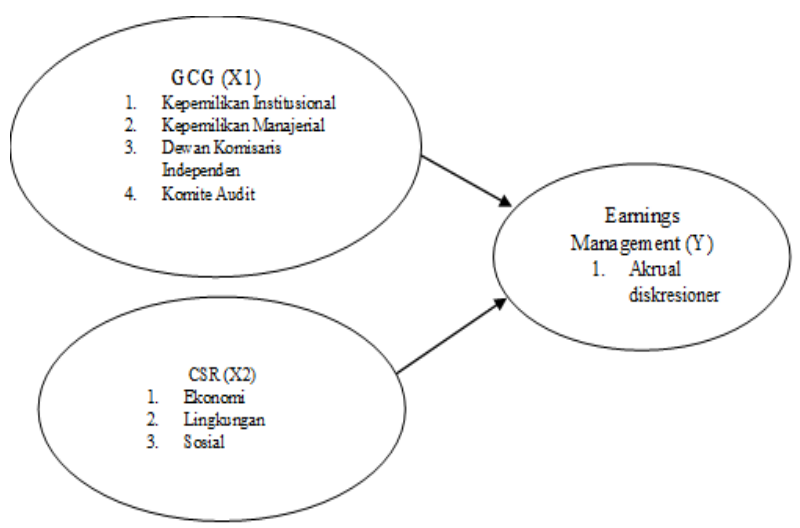

Gambar 1. Kerangka Konseptual

Dimana :

$\mathrm{X} 1=$ Good Corporate Governance

$\mathrm{X} 2=$ Corporate Social Responsibility

$\mathrm{Y}=$ Earnings Management

\section{Hipotesis Penelitian}

Dari kerangka pemikiran di atas dapat disusun hipotesis penelitian sebagai berikut:

H1: Good Corporate Governance berpengaruh negative dan signifikan terhadap Earnings Management.

H2 : Corporate Social Responsibility berpengaruh negative dan signifikan terhadap Earnings Management.

\section{Jenis Penelitian}

Penelitian ini menggunakan pendekatan kuantitatif yang bertujuan untuk mengetahui pengaruh variabel independen, yaitu Good Corporate Governance (GCG) dan Corporate Social Responsibility (CSR) terhadap variabel dependen yaitu Earnings Management.

\section{Definisi Operasional Variabel.}

Variabel good corporate governance (GCG) terdiri dari empat indikator yang dapat digunakan untuk mengukur good corporate governance yaitu proporsi dari kepemilikan institusional, kepemilikan manajerial, dewan komisaris, dan kualitas audit. 
Kepemilikan Institusional

Dalam penelitian ini kepemilikan institusional dapat diukur dengan persentase jumlah saham yang dimiliki institusional. (Agustia, 2013)

$$
K I=\frac{\text { Jumlah saham yang dimiliki institusional }}{\text { Total saham yang beredar }} \times 100 \%
$$

Kepemilikan Manajerial

Dalam penelitian ini kepemilikan manajerial dapat diukur dengan persentase jumlah kepemilikan saham yang dimiliki manajer (Agustia, 2013)

$$
K M=\frac{\text { Jumlah saham yang dimiliki manajerial }}{\text { Total saham yang beredar }} \times 100 \%
$$

Dewan Komisaris Independen

Dalam penelitian ini dewan komisaris yang dimaksud adalah banyaknya jumlah anggota dewan komisaris di perusahaan (Agustia, 2013)

$$
D K I=\frac{\text { Jumlah } \text { komisaris independen }}{\text { jumlah dewan komisaris }} \times 100 \%
$$

Komite Audit

Penelitian ini komite audit diukur dengan jumlah anggota komite audit (Agustia, 2013)

$$
K A=\sum \text { anggota komite audit }
$$

Variabel Corporate Social Responsibility dalam penelitian ini diukur dengan corporate social responsibility disclosure index (CSRDI) yang telah ditentukan oleh global reporting intitiative (GRI). Pengungkapan GRI standard terdiri dari 77 item yang terbagi menjadi tiga indikator, ekonomi, sosial, dan sosial. Perusahaan yang mengungkapkan item tanggung jawab sosial diberi nilai 1 , dan nilai 0 jika tidak diungkapkan.

Variabel Earnings Management penelitian ini menggunakan diskresioner akrual sebagai indikator pada manajemen laba. Pengukuran manajemen laba menggunakan modified Jones model (Agustia, 2013).

\section{Sumber Data Penelitian}

Penelitian ini menggunakan data sekunder yang berupa dokumentasi laporan tahunan (annual report) pada perusahaan food and beverage periode 2014-2019 yang diperolah dari website www.idx.com.

\section{Teknik Analisis Data}

Analisis data pada penelitian ini menggunakan pendekatan Partial Least Square (PLS). PLS adalah model persamaan Structural Equation Modeling (SEM) menggunakan software WarpPLS 7.0. Uji analisis data menggunakan metode SEM-PLS dilakukan dengan outer model (model pengukuran) yang terdiri dari significant of weight dan nilai VIF. Inner model (model struktual) yang terdiri dari $\mathrm{R}^{2}$, $\mathrm{Q}^{2}$, Model fit.

Uji hipotesis pada penelitian ini menggunakan pengujian langsung. Kriteria penerimaan atau penolakan hipotesis yaitu:

1) Jika p value $>0,05$, maka Ho diterima dan $\mathrm{Ha}$ ditolak

2) Jika p value $<0,05$, maka Ho ditolak dan $\mathrm{Ha}$ diterima

\section{HASIL PENELITIAN}

Tabel 1 Statistik Deskriptif

\begin{tabular}{cccccc}
\hline & $\mathbf{N}$ & $\begin{array}{c}\text { Minim } \\
\mathbf{u m}\end{array}$ & $\begin{array}{c}\text { Maksi } \\
\text { mum }\end{array}$ & Mean & $\begin{array}{c}\text { Std } \\
\text { Deviation }\end{array}$ \\
\hline $\mathrm{KI}$ & 42 & .36 & .96 & .6467 & .17898 \\
$\mathrm{KM}$ & 42 & .00 & .36 & .0521 & .09164 \\
$\mathrm{DKI}$ & 42 & .33 & .50 & .3736 & .06903 \\
$\mathrm{CSR}$ & 42 & .05 & .31 & .1274 & .07752 \\
$\mathrm{EM}$ & 42 & -.06 & .01 & -.0002 & .01070 \\
\hline
\end{tabular}

Sumber : data diolah

Berdasarkan tabel 1 indikator Kepemilikan Institusional (KI) menunjukkan bahwa nilai terendah (minimum) sebesar 0,36 dan nilai tertinggi (maximum) sebesar 0,96. Dari data diatas dapat diketahui bahwa nilai rata-rata Kepemilikan Institusional perusahaan sebesar 0,6467 atau 64,67 $\%$.

Indikator Kepemilikan Manajerial (KM) menunjukkan bahwa nilai minimum sebesar 0,00 yang berarti tidak ada kepemilikan manajerial dalam perusahaan dan nilai maximum sebesar 0,36 . Nilai rata-rata kepemilikan manajerial perusahaan sebesar 0,0521 atau $5,21 \%$.

indikator Dewan Komisaris Independen (DKI) menunjukkan bahwa nilai minimum sebesar 0,33 dan nilai maximum sebesar 0,50 . Nilai rata-rata dewan komisaris independent pada perusahaan food and beverages sebesar 0,3736 atau 37,36 \%.

Variabel (CSR) menunjukkan bahwa nilai minimum yang didapat sebesar 0,05 pada perusahaan ALTO dan nilai maximum sebesar 0,31 yang dimiliki oleh perusahaan INDF pada tahun 2017-2019. Nilai rata-rata pengungkapan CSR pada perusahaan food and beverage sebesar 0,1274 atau $12,74 \%$.

Variabel Earnings Management menunjukkan bahwa akrual diskresioner dengan nilai minimum 
yang didapat sebesar $-0,06$ pada perusahaan ALTO dan nilai maximum sebesar 0,01 . Nilai rata-rata akrual diskresioner pada perusahaan food and beverages sebesar $-0,0002$.

\section{Outer Model}

Tabel 1. Outer Model

\begin{tabular}{lccccccccc}
\hline & GCG & CSR & EM & Type & SE & $\begin{array}{c}\text { P } \\
\text { value }\end{array}$ & VIF & WLS & ES \\
\hline KI & -0.596 & 0.000 & 0.000 & Formatif & 0.120 & $<0.001$ & 2.176 & 1 & 0.558 \\
\hline KM & 0.488 & 0.000 & 0.000 & Formatif & 0.126 & $<0.001$ & 1.967 & 1 & 0.376 \\
& & & & & & & & & \\
\hline DKI & 0.206 & 0.000 & 0.000 & Formatif & 0.142 & 0.077 & 1.603 & 1 & 0.066 \\
& & & & & & & & & \\
\hline CSR & 0.000 & 1.000 & 0.000 & Formatif & 0.101 & $<0.001$ & 0,000 & 1 & 1.000 \\
& & & & & & & & & \\
\hline EM & 0.000 & 0.000 & 1.000 & Formatif & 0.101 & $<0.001$ & 0,000 & 1 & 1.000
\end{tabular}

Sumber : output warppls 7.0 dan data diolah

Pada penelitian ini variabel GCG awalnya menggunakan 4 indikator, namun berkurang menjadi 3 indikator. Indikator Komite Audit dihapus karena terdapat hasil pada significant of weight yang didapat sebesar 0,18 sehingga sangat jauh dengan syarat pengukuran. Berdasarkan tabel 2 diketahui bahwa 2 indikator variabel GCG memiliki nilai $\mathrm{p}$ value sebesar <0,001, dan 1 indikator dengan hasil p-value sebesar 0,077. Sedangkan pada indikator CSR, dan EM dengan hasil p-value sebesar $<0,001$. Nilai VIF semua indikator pada tabel tersebut menunjukkan hasil $<2,5$ yang menyatakan bahwa tidak terjadi multikolinearitas.

\section{Inner Model}

1. Koefisien Determinasi $\left(\mathrm{R}^{2}\right)$

\begin{tabular}{ccc}
\multicolumn{3}{c}{ Tabel 2. Koefisien Determinasi } \\
\hline GCG & CSR & EM \\
\hline & & $\mathbf{0 . 1 7 7}$ \\
\hline
\end{tabular}

Sumber : output warppls 7.0 dan data diolah

Pada tabel 3 menunjukkan bahwa nilai koefisien determinasi $\left(\mathrm{R}^{2}\right)$ sebesar 0,177 atau sebesar $17,7 \%$, dapat diartikan bahwa pengaruh variabel independen terhadap variabel dependen sebesar $17,7 \%$ dan sisanya sebesar 82,3 \% dijelaskan oleh variabel diluar penelitian.

2. Relevansi Prediktif $\left(\mathrm{Q}^{2}\right)$

Tabel 3. Relevansi Prediktif

\begin{tabular}{lll}
\hline GCG & CSR & EM \\
\hline & & 0.164 \\
\hline
\end{tabular}

Sumber : output warppls 7.0 dan data diolah

Pada tabel 4 diatas menunjukkan hasil nilai Q2 sebesar 0,164 yang artinya jika nilai dari Q2 >0 maka variabel independent mempunyai relefansi terhadap variabel dependen.

\section{Model Fit}

Tabel 4. Model Fit

\begin{tabular}{lll} 
Model & Fit Indices & $\boldsymbol{P}$-Values \\
\hline APC & 0.221 & $P=0.031$ \\
ARS & 0.177 & $P=0.056$ \\
AVIF & 1.048 & Good if $<5$
\end{tabular}

Sumber : output warppls 7.0 dan data diolah

Tabel 5 diatas menunjukkan bahwa nilai APC memiliki fit indecies sebesar 0,221 , nilai $p$-value sebesar 0,031. Nilai ARS fit indicies menunjukkan sebesar 0,177 , nilai p-value sebesar 0,056. Nilai AVIF menunjukkan hasil sebesar 1,048 memenuhi syarat $<5$, penelitian ini dinyatakan fit sehingga tidak terjadi multikoliniearitas.

\section{Uji Hipotesis}

Output pengujian pada tabel 6 di atas menunjukkan hasil bahwa hipotesis pertama variabel eksogen GCG (X1) berpengaruh positif dan tidak signifikan terhadap variabel endogen Earnings Management (Y), dimana nilai koefisien sebesar 0,029 dengan p-value >0,05 sebesar 0,424. Sedangkan variabel eksogen CSR (X2) memiliki pengaruh signifikan terhadap Earnings Management (Y) dimana nilai koefisien sebesar 0,413 dengan $\mathrm{p}$ values $<0,001$.

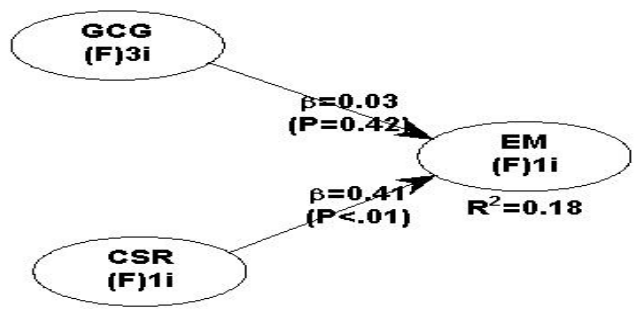

Gambar 2. Coefficient and P-Values

Tabel 5. Coefficient and P-values

\begin{tabular}{llll}
\hline Coefficient & P-Values & Keterangan & \\
\hline GCG $\rightarrow$ & 0,029 & 0,424 & $\begin{array}{l}\text { Berpengaruh } \\
\text { positif dan } \\
\text { tidak } \\
\text { sM }\end{array}$ \\
& & & \\
& & & $\begin{array}{l}\text { serpnifikangaruh } \\
\text { positif dan } \\
\text { signifikan }\end{array}$ \\
\hline CSR $\rightarrow 0,413$ & $<0.001$ & \\
EM & & &
\end{tabular}

Sumber : data diolah 


\section{PEMBAHASAN}

\section{Pengaruh Good Corporate Governance terhadap Earnings Management}

Berdasarkan hasil analisis data dan uji WarpPls 7.0 hipotesis pertama ditolak. Keadaan ini dapat dilihat dari nilai coefficients sebesar 0,029 dan p-value sebesar 0,424. Dapat diartikan bahwa Good Corporate Governance dengan proksi Kepemilikan Institusional, Kepemilikan Manjaerial, dan Dewan Komisaris Independen tidak berpengaruh terhadap Earnings Management pada perusahaan food and beverage yang terdaftar di BEI.

Hal ini menunjukkan bahwa kepemilikan institusional dalam menjalankan perannya berkurang dalam melakukan pengawasan terhadap kinerja manajemen dan investor institusi hanya menjalankan peran sebagai pemilik sementara perusahaan yang hanya fokus kepada laba agar dapat mencapai target laba yang diinginkan, sehingga adanya kepemilikan institusional belum tentu dapat meningkatkan pengawasan secara efektif.

Kepemilikan manajerial yang terlihat dari statistik deskriptif bahwa kepemilikan manajerial dalam perusahaan food and beverage di Indonesia masih sangat relative rendah. Kepemilikan saham yang dimiliki oleh manajer dalam perusahaan tidak mendorong praktik manajemen laba, dan semakin kecil kepemilikan manajerial maka manajer mempunyai hak dalam pengambilan keputusan juga kecil. Besar kecilnya

Dewan Komisaris Independen yang terdapat dalam perusahaan tidak mempengaruhi tindakan manajemen laba, peran dari dewan komisaris independent dampaknya kurang terhadap perusahaan karena mungkin dengan pengangkatan dewan komisaris independent oleh perusahaan hanya untuk memenuhi syarat namun tidak untuk menjalankan Good Corporate Governance. Dapat disimpulkan bahwa dengan semakin naik atau turunnya Good Corporate Governance yang dilakukan oleh perusahaan maka tidak akan mempengaruhi manajemen melakukan tindakan Earnings Management atau tidak.

Berdasarkan penjelasan diatas, penelitiann ini sejalan dengan penelitian yang dilakukan oleh Agustia (2013) dan Natasha Suri (2018) yang menyatakan bahwa mekanisme Good Corporate Governance tidak berpengaruh terhadap Earnings Management.

\section{Pengaruh Corporate Social Responsibility terhadap Earnings Management}

Berdasarkan hasil analisis data dan uji WarpPls 7.0 keadaan ini dapat dilihat bahwa nilai coefficients sebesar 0,413 dan p-value sebesar
$<0,001$. Dapat diartikan bahwa Corporate Social Responsibility berpengaruh positif terhadap Earnings Management. Perusahaan yang melakukan pengungkapan informasi mengenai tanggung jawab sosial semakin tinggi maka semakin mempengaruhi perusahaan untuk melakukan tindakan manajemen laba.

Hasil penelitian ini sesuai dengan pernyataan Arief dan Ardiyanto (2014) yang menjelaskan bahwa penerapan CSR di Indonesia sangat dipengaruhi oleh cara pandang dan budaya masyarakat sekitar yang berpikir kegiatan CSR hanya sebagai donasi kepada masyarakat.

Berdasarkan penjelasan di atas, hasil penelitian ini sejalan dengan penelitian yang dilakukan oleh Suryani dan Herianti (2015) dan Sitanggang dan Ratmono (2019) yang menyatakan bahwa Pengungkapan Corporate Social Responsibility berpengaruh positif terhadap Earnings Management

\section{SIMPULAN DAN SARAN}

\section{Simpulan}

Good Corporate Governance tidak berpengaruh terhadap Earnings Management karena kepemilikan institusional belum tentu dapat meningkatkan pengawasan secara efektif, kepemilikan manajerial masih sangat relative rendah, dan besar kecilnya dewan komisaris independen hanya untuk memenuhi syarat dari pemerintah sehingga tidak mempengaruhi terjadinya tindakan Earnings Management.

$$
\text { Pengungkapan Corporate Social }
$$

Responsibility berpengaruh terhadap Earnings Management. Karena Corporate Social Responsibility akan membuat citra perusahaan menjadi positif dan dapat menarik perhatian para investor yang menggunakan laporan keuangan dan membuat para investor tidak fokus pada pengawasan dan mendeteksi tindakan Earnings Management

Adapun saran-saran yang dapat diberikan melalui hasil dari penelitian ini adalah sebagai berikut

\section{Saran}

\section{Bagi Perusahaan}

Diharapkan dapat membantu memberikan informasi tambahan bagi manajer perusahaan, dapat mengevaluasi maupun melakukan pengawasan yang lebih baik lagi terhadap mekanisme good corporate governance dan diharapkan perusahaan dapat meningkatkan pengungkapan corporate social responsibility.

2. Bagi Universitas

Hasil penelitian ini diharapkan dapat digunakan sebagai menambah pengetahuan, 
wawasan, dan koleksi perpustakaan perguruan tinggi serta dapat digunakan sebagai bahan pertimbangan dan referensi bagi pihak yang akan melakukan penelitian dengan jenis pemasalahan yang sama

3. Bagi peneliti selanjutnya

Hasil dari penelitian ini diharapkan dapat meneliti atau menambah variabel-variabel lain diluar variabel pada penelitian ini dan memperluas objek penelitian.

\section{DAFTAR PUSTAKA}

Abduh, M. M., dan Rusliati, E. (2018). Mekanisme Good Corporate Governance dan Kinerja Keuangan, 11(2), 80-87.

Agustia, D. (2013). Pengaruh Faktor Good Corporate Governance, Free Cash Flow, dan Leverage Terhadap Manajemen Laba. Jurnal Akuntansi Dan Keuangan, 15(1), 27-42.

Anas, A., Rashid, H. M. A., dan Annuar, H. A. (2015). The effect of award on CSR disclosures in annual reports of Malaysian PLCs. Social Responsibility Journal, 11(4), 831-852. https://doi.org/10.1108/SRJ-02-20130014

Arief, A., dan Ardiyanto, M. D. (2014). Pengaruh Pengungkapan Corporate Social Responsibility Terhadap Manajemen Laba (Studi Kasus Pada Perusahaan Non Keuangan dan Jasa yang Terdaftar di BEI tahun 2010-2012), 3(2003), $102-110$.

Asward, I., dan Lina, L. (2015). Pengaruh Mekanisme Corporate Governance terhadap Manajemen Laba dengan Pendekatan Conditional Revenue Model. Jurnal Manajemen Teknologi, 14(1), 15-34.

Beneish, M. D. (2001). Earnings management: A perspective. Managerial Finance, 27(12), 317. https://doi.org/10.1108/03074350110767411

Deegan, C., Rankin, M., dan Tobin, J. (2002). An examination of the corporate social and environmental disclosures of BHP from 19831997: A test of legitimacy theory. Accounting, Auditing dan Accountability Journal (Vol. 15).
Dewi, P. P., Ayu, I. G., dan Eka, E. (2019). Kinerja Lingkungan , Manajemen Laba , Corporate Governance Dan Corporate Social Responsibility ( CSR ), 28, 569-589.

FCGI. (2002). Peranan Dewan Komisaris dan Komite Audit dalam Pelaksanaan Corporate Governance ( Tata Kelola Perusahaan ). Seri Tata Kelola Perusahaan (Corporate Governance), II(2002), 37.

Jensen, M. C., dan Meckling, W. H. (1976). Theory of the firm: Managerial behavior, agency costs and ownership structure. Journal of Financial Economics.

Mahariana, I., dan Ramantha, I. (2014). Pengaruh Kepemilikan Manajerial Dan Kepemilikan Institusional Terhadap Manajemen Laba Pada Perusahaan Manufaktur Di Bei. E-Jurnal Akuntansi, 7(3), 688-699.

Natasha Suri, I. P. D. (2018). Pengaruh Mekanisme Good Corporate Governance Terhadap Manajemen Laba (Studi pada Perusahaan Manufaktur Sektor Food and Beverages yang Terdaftar di Bursa Efek Indonesia periode 2012 - 2016). Jurnal Akuntansi.

Pratiwi, H. R. (2019). Membedah Keanehan Laporan Keuangan Garuda Indonesia 2018.

Ratmono, D., Purwanto, A., dan Cahyonowati, N. (2015). Hubungan Tingkat Pengungkapan dan Kinerja Corporate Social Responsibility Serta Manajemen Laba: Pengujian Teori Ekonomi dan Sosio-Politis. Jurnal Akuntansi Dan Keuangan, 16(2), 63-73.

Ricardo, D., dan Faisal, F. (2015). Pengaruh Pengungkapan Corporate Social Responsibility Terhadap Praktik Manajemen Laba. Diponegoro Journal of Accounting.

S. Willy Rahadyan, A. purwanto. (2015). Pengaruh Surplus Free Cash Flow Dan Mekanisme Good Corporate Governance Terhadap Manajemen Laba, 4(2), 906-919.

Scott, W. R. (2015). Financial accounting theory. Prentice Hall Canada. 